\title{
Correlation between Symptoms and ELISA for the Detection of Cucumber Mosaic Virus in Bell Pepper
}

\author{
Shelly Kapoor, Abhilasha Sharma and Anil Handa* \\ Plant Virology Laboratory, Dr. Y S Parmar University of Horticulture and Forestry, \\ Nauni-173230, Solan, Himachal Pradesh, India \\ *Corresponding author
}

A B S T R A C T

\section{Keywords \\ Correlation, ELISA, Cucumber Mosaic Virus, Bell pepper \\ Article Info \\ Accepted: 02 May 2018 Available Online: 10 June 2018}

Field surveys were conducted for collection of CMV virus isolates in bell pepper depicting a wide range of symptoms ranging from mosaic, mottling, yellow discoloration, vein clearing, leaf deformation, shoe stringing or leaf narrowing, stunted growth to reduced fruit size. In an attempt to correlate the symptoms with virus concentration in different isolates, DAS-ELISA was performed on symptomatic plants and CMV was detected in majority of the isolates. It was observed that the plants with shoe stringing (typical symptom of CMV in bell pepper) had the highest O.D. value whereas plants with puckering had very low O.D. value. This study signifies the importance of DAS-ELISA in mass screening of bell pepper germplasm to determine the sources of resistance to CMV.

\section{Introduction}

The genus Capsicum comprising of hot pepper, bell pepper, paprika and cayenne belongs to the family, Solanaceae. Despite being a single species, $C$. annuum has many forms such as hot pepper, bell pepper, paprika, jalapeno, pimento and Aleppo pepper. Hot and bell peppers within the genus Capsicum are important spice and vegetable crops of immense commercial importance and are being cultivated widely throughout the world. The major chilli and bell pepper growing countries are India, China, Indonesia, Korea, Mexico and Nigeria. In India, it is cultivated over an area of about 32150 hectares with an annual production of 1.82 lakh metric tonnes (Anonymous, 2016). Within India, it is cultivated in almost all the states. However, major production comes from Andhra Pradesh, Karnataka, Maharashtra, Orissa, Rajasthan, Tamil Nadu and West Bengal. Himachal Pradesh is also a leading bell pepper growing state in the country where bell pepper is grown as an off-season vegetable with an area of 2070 hectares and a production of 34.13 thousand metric tonnes (Anonymous, 2016).

Many insects and diseases (fungal, bacterial and viral) are becoming the major constraints for the production of bell pepper in India. Among these, viruses are major production constraints resulting in yield reduction up to 100 per cent (Lochart and Fischer, 1976). More than 45 viruses have been reported to 
infect bell pepper across the world (Bidari and Reddy, 1990). Out of these viruses, chilli vein mottle virus (ChiVMV), cucumber mosaic virus (CMV), capsicum chlorosis viruses $(\mathrm{CaCV})$, chilli leaf curl virus (ChiLCV), tobacco mosaic virus (TMV), potato virus $\mathrm{Y}$ and groundnut bud necrosis virus (GBNV) are the most serious pathogens in terms of incidence and yield loss (Verma and Sharma, 1999). CMV is the most predominant virus and is prevalent in all pepper growing areas as single or mixed infections resulting significant yield losses. Several strains of the virus capable of infecting peppers are known to exist and are spread all over the world. Cucumber mosaic virus is the type species in the genus Cucumovirus representing family Bromoviridae (Roossinck et al., 1999). It has a wide host range including plants from approximately 365 genera and at least 85 families and is efficiently transmitted in a nonpersistent manner by more than 75 species of aphids (Kaplan et al., 1997).

CMV infected bell pepper plants typically express symptoms of mosaic, mottling, yellow discoloration, vein clearing, leaf deformation, shoe stringing or leaf narrowing, stunted growth, reduced fruit size and whitish streaks on green fruits. Detailed studies on serological detection of CMV strains infecting bell pepper in Himachal Pradesh is lacking at present. In order to provide more insight into ELISA based detection of CMV in bell pepper, the present study was carried out with the objective of identifying the virus using DASELISA.

\section{Materials and Methods}

\section{Collection of isolates}

During field survey, leaf samples from infected bell pepper plants showing mosaic and distorted leaf symptoms and healthy plants without any symptoms were collected and brought to the laboratory for serological detection of the causal virus in the sample by DAS-ELISA using CMV antisera procured from BIOREBA, Switzerland.

\section{ELISA detection}

DAS (Double Antibody Sandwich) form of ELISA was used for the detection of the causal virus in the test samples. The procedure for conducting DAS-ELISA is presented hereunder.

The protocol given by Clark and Adams (1977) was followed for conducting DASELISA tests. Wells of the microtitre plate (NUNC maxisorp certified microplates) except those of the top and bottom rows and rows on the extreme left and right, were filled with $100 \mu \mathrm{l}$ aliquots of coating antibodies diluted in $1 \mathrm{X}$ coating buffer $(1: 500$ ratio $\mathrm{v} / \mathrm{v})$. The plate was incubated in humid box for 4 hours at $37^{\circ} \mathrm{C}$. The coating antibody suspension was removed by shaking out the plate over the wash basin. The wells were filled with 1X PBS-Tween and kept for 2 minutes with gentle shaking. The plate was emptied and filled again with PBS-Tween. The washing was repeated three times. The test samples were ground in $1 \mathrm{X}$ extraction buffer (1:10 ratio w/v). All coated wells were filled with $100 \mu \mathrm{l}$ aliquots of test sample (each sample in duplicate) besides positive and negative control wells. The plates were incubated in humid box overnight at $4 \pm 1^{\circ} \mathrm{C}$. The washing steps were repeated as mentioned above. The alkaline phosphatase (ALP) conjugate antibodies were filled in each well with $100 \mu \mathrm{l}$ aliquots after diluting it in $1 \mathrm{X}$ conjugate buffer at a ratio of 1:500 (v/v). The plate was incubated in humid box for 2 hours at $37^{\circ} \mathrm{C}$. The washing was done as mentioned above. The p-nitrophenyl phosphate (pNPP) substrate was dissolved in $1 \mathrm{X}$ substrate buffer. Each well was filled with $100 \mu \mathrm{l}$ aliquots of substrate. The plates were kept in humid box 
in dark condition at room temperature until a yellow colour was clearly visible in the positive control (usually between 30 to 60 minutes). If desired, the reaction was stopped by adding $50 \mu \mathrm{l}$ of $3 \mathrm{M} \mathrm{NaOH}$ to each well. The results were assessed in the same manner as for DAC-ELISA.

\section{Results and Discussion}

\section{Survey and symptomatology}

In the present study, cucumber mosaic virus infecting bell pepper at different experimental farms belonging to various departments of Dr. Y S Parmar University of Horticulture and Forestry, Nauni, Solan, Himachal Pradesh were surveyed to record the incidence of CMV and also to collect different virus isolates on the basis of different type of symptoms observed during field surveys. The incidence of virus diseases in bell pepper grown at different locations ranged from 15.80 - 56.55 percent during the period of survey. Since the symptoms on bell pepper were observed to be of complex nature, the incidence of CMV could not be recorded specifically. However, to confirm the positive association of CMV with bell pepper crops surveyed, DAS-ELISA was performed to identify CMV in symptomatic plants.

The most prominent and striking symptoms of CMV in infected bell pepper plants were in the form of mosaic, mottling, vein clearing, leaf deformation, shoe stringing or leaf narrowing, stunted growth and reduced fruit size (Fig. 1-4). Studies conducted on CMV in bell pepper from India and many other countries have observed mosaic, mottling, shoe stringing, leaf narrowing and stunted growth to be associated with CMV infection in bell pepper (Sevik et al., 2003; Korbin and Kaminska, 1998; Khan et al., 2006).

\section{Table.1 Reaction of virus isolates to CMV in DAS- ELISA}

\begin{tabular}{|c|c|c|c|c|}
\hline Location & Isolate & Symptoms & $\begin{array}{l}\text { Reaction in } \\
\text { DAS-ELISA }\end{array}$ & $\begin{array}{c}\text { O.D. Value } \\
\left(\mathbf{A}_{405} \mathrm{~nm}\right)\end{array}$ \\
\hline \multirow{3}{*}{$\begin{array}{l}\text { Experimental } \\
\text { Farm, Naganji }\end{array}$} & 1 & Mottling & + & 0.265 \\
\hline & 2 & Puckering & - & 0.091 \\
\hline & 3 & Vein clearing & + & 0.283 \\
\hline \multirow{3}{*}{$\begin{array}{l}\text { Experimental } \\
\text { Farm, Khaltoo }\end{array}$} & 4 & Mosaic & + & 0.424 \\
\hline & 5 & Shoe stringing & + & 0.517 \\
\hline & 6 & Blistering & - & 0.115 \\
\hline \multirow{3}{*}{$\begin{array}{l}\text { Experimental } \\
\text { Farm, Nauni }\end{array}$} & 7 & Leaf distortion & + & 0.279 \\
\hline & 8 & Yellowing & - & 0.104 \\
\hline & 9 & Stunted growth & + & 0.238 \\
\hline \multirow{3}{*}{$\begin{array}{l}\text { Experimental } \\
\text { Farm, Pandah }\end{array}$} & 10 & Mottling & + & 0.355 \\
\hline & 11 & Leaf narrowing & + & 0.411 \\
\hline & 12 & Leaf curling & - & 0.089 \\
\hline \multirow{3}{*}{$\begin{array}{l}\text { Experimental } \\
\text { Farm, Bhajo }\end{array}$} & 13 & Vein clearing & + & 0.290 \\
\hline & 14 & Reduced fruit size & + & 0.250 \\
\hline & 15 & Shoe stringing & + & 0.613 \\
\hline
\end{tabular}


Fig.1 Mosaic and shoe stringing

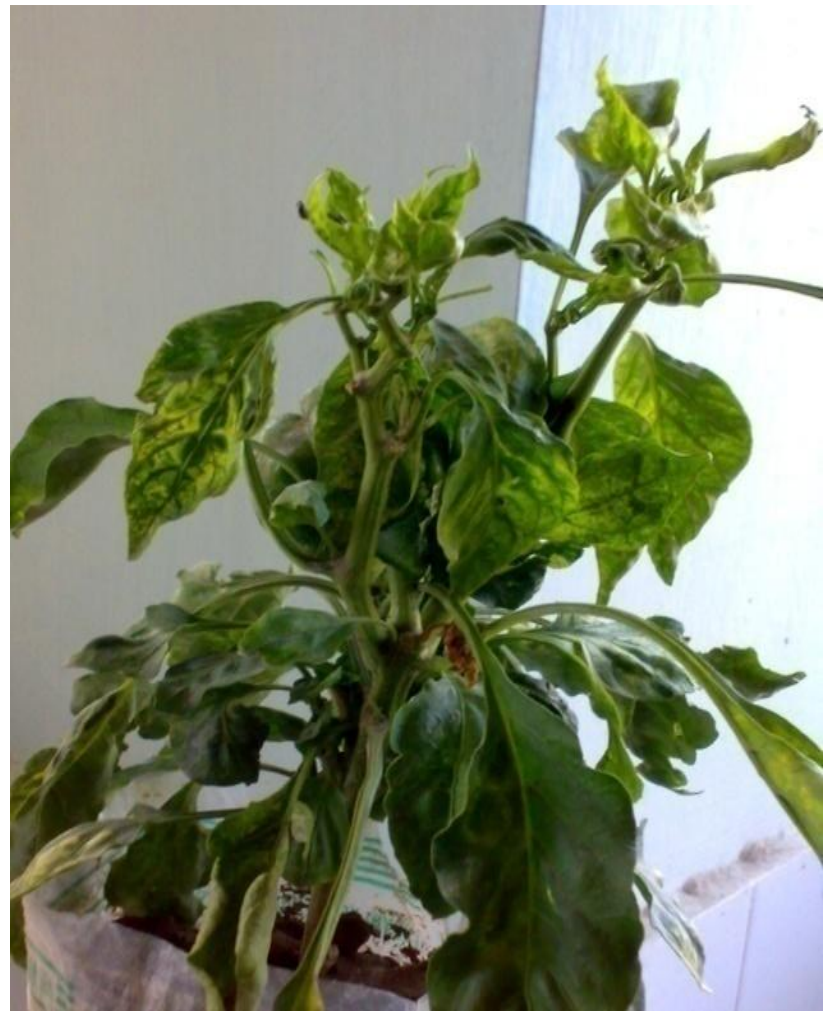

Fig.2 Mottling in leaves

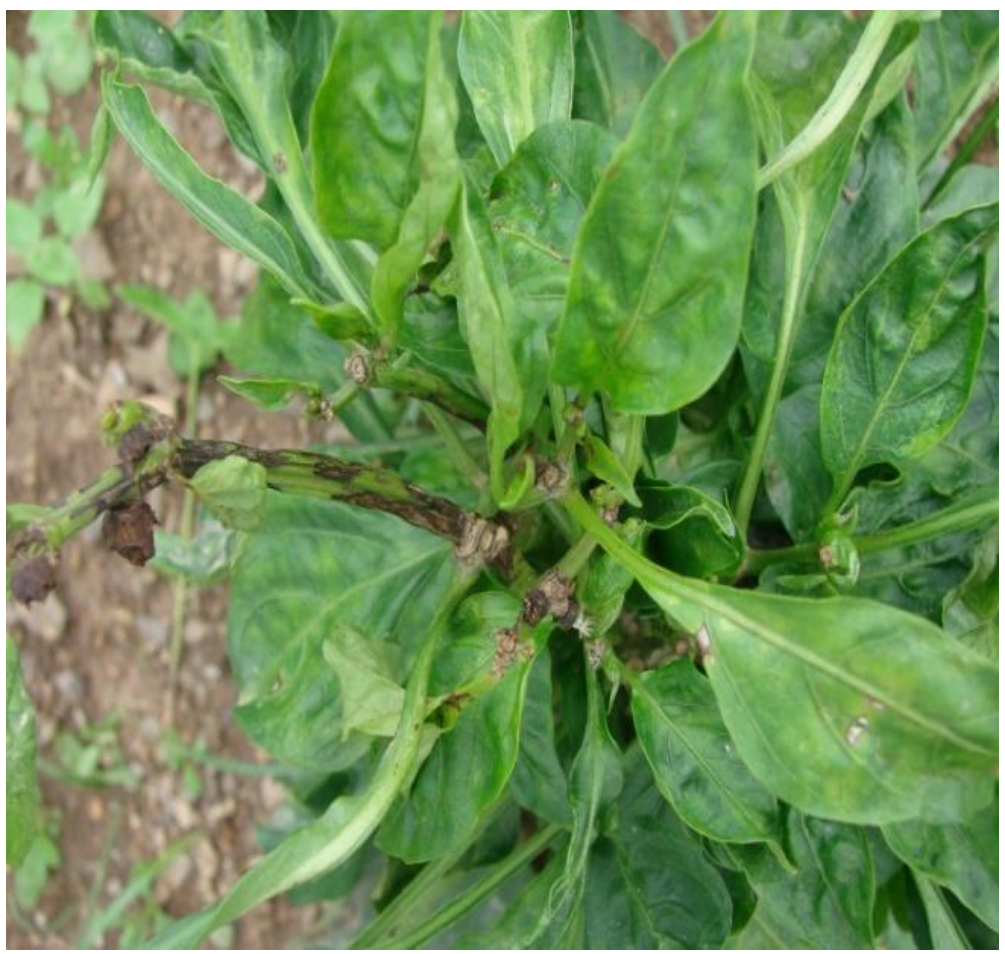


Fig.3 Vein clearing and leaf deformation

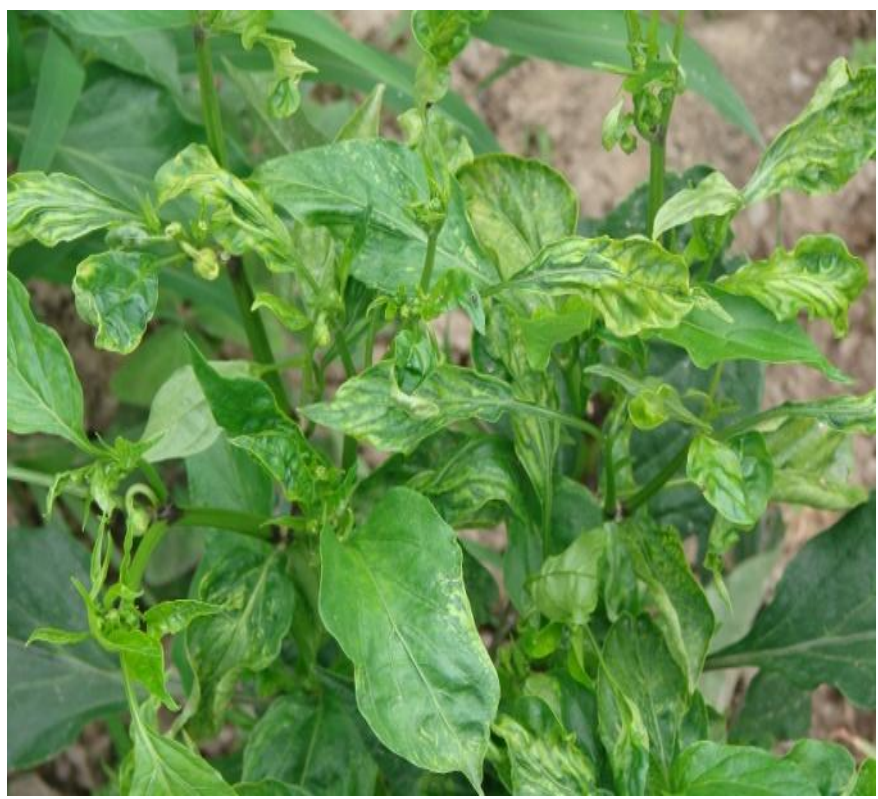

Fig.4 Reduced fruit size

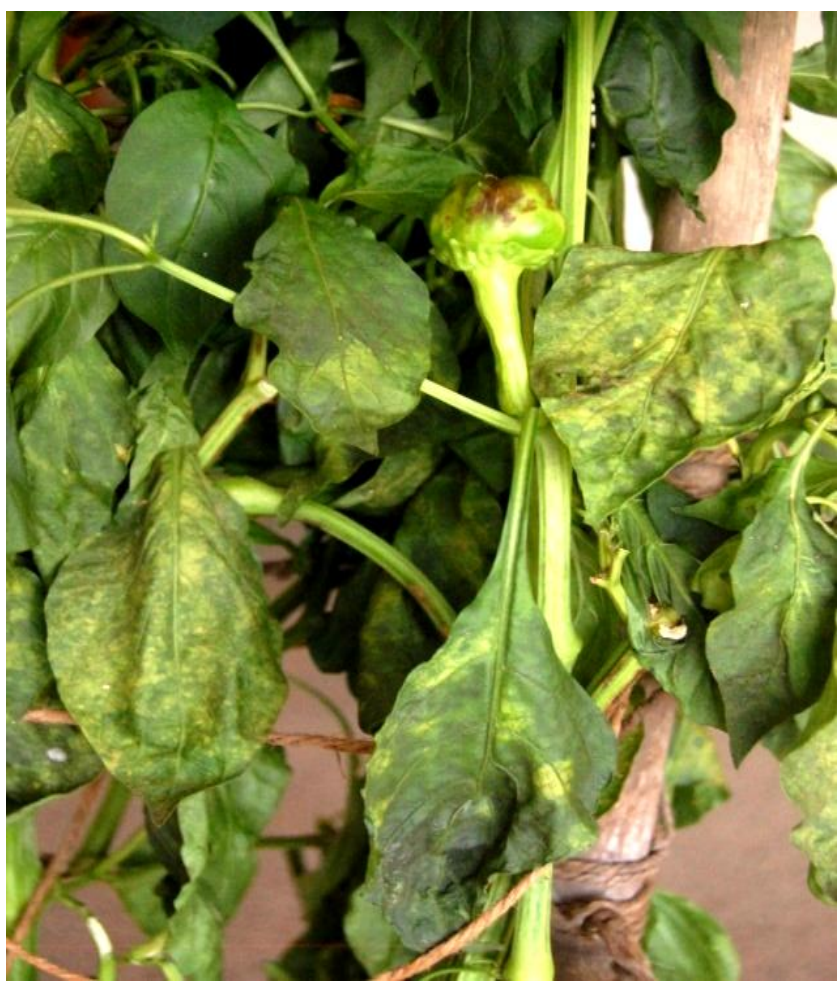

\section{DAS-ELISA}

Positively marked bell pepper plants growing at different experimental farms were screened by DAS-ELISA to confirm the presence of CMV. Individual symptomatic plant was considered to be an independent sample. Since varied symptoms were observed in the 
field, each plant exhibiting different symptom was considered to be representing different virus isolate. On the basis of these symptoms, a large number of virus isolates were collected from different experimental farms and loaded into ELISA plate as an individual sample. It is evident from the data presented in Table 1 that out of a total of 15 virus isolates collected from five different experimental farms of Dr. Y.S. Parmar University of Horticulture and Forestry, Nauni, Solan, Himachal Pradesh, 11 virus isolated tested positive in DAS- ELISA tests as evident from the O.D. values recorded in microprocessor based ELISA plate reader. The highest O.D value of 0.613 was recorded from virus isolate 15 (collected from Experimental Farm, Bhajo) exhibiting shoe stringing symptoms followed by virus isolate 5 (collected from Experimental Farm, Khaltoo) also exhibiting shoe stringing symptoms. Many workers have also reported shoe stringing to be the major symptom of CMV on bell pepper (Kamiska et al., 2005; Kumari et al., 2013; Iqbal et al., 2011). Virus isolate with puckering, blistering, yellowing and leaf curling type of symptoms were found to be free from CMV as indicated by negative ELISA results. A critical scanning of the literature on symptomatology of CMV in bell pepper reveals that none of these symptoms are associated with CMV anywhere in the world.

The present studies have clearly established the importance of ELISA for detecting CMV in bell pepper as the virus was found in detectable limits in all virus isolates exhibiting typical symptoms of CMV infection. These findings further highlight the importance of ELISA for large scale screening of germplasm to ascertain the sources of resistance to this virus. Many reports available in the literature also emphasise the need of ELISA in the detection of CMV in symptomatic plants and also stresses upon its utility in mass screening of germplasm (Soleimani et al., 2014; Ashfaq et al., 2014; Xu et al., 2006; Perry et al., 1993).

\section{References}

Anonymous, 2016. Indian Horticulture Database. National Horticulture Board, Gurgaon.

Ashfaq, M., Iqbal, S., Mukhtar, T. and Shah, H. 2014. Screening for resistance to Cucumber mosaic cucumovirus in chilli pepper. Journal of Animal and Plant Sciences., 24: 791-795.

Bidari, V.B. and Reddy, H.R. 1990. Identification of naturally occurring viruses on commercial cultivars of chilli. Mysore Journal of Agricultural Sciences., 24: 45-51.

Clark, M.F. and Adams, A.N. 1977. Characteristics of the microplate method of enzyme-linked immunosorbent assay for the detection of plant viruses. Journal of general virology., 34:475- 483.

Iqbal, S., Ashfaq, H. and Shah, H. 2011. Biological Characterization of Pakistani isolates of Cucumber mosaic cucumovirus (CMV). Pakistan. Journal of Botany., 43:3041-3047.

Kamiska, M., Hannaliwa and Tadeusz M, 2005. Partial characterisation of Cucumber mosaic virus isolate infecting Lonicera caprifolium L. plants, Acta. Sci. Pol. Hortorum Cultus., 4:3-10.

Kaplan, I.B., Gal-On, A. and Palukaitis, P. 1997. Characterization of cucumber Mosaic virus. III. Localization of sequences in the movement protein controlling systemic infection in cucurbits. Virology., 230: 343-349.

Khan, S.M., Raj S.K, Bano, T. and Garg, V.K. 2006. Incidence and management of mosaic and leaf curl diseases in cultivars chilli (Capsicum anпuиm L.). 
Journal of Food, Agriculture and Environment., 4:171-174.

Korbin, M. and Kaminska, M., 1998. Characterization of Cucumber mosaic cucumovirus isolates. Phytopathologia Polonica., 16: 71-84.

Kumari, R., Bhardwaj, P., Singh, L., Zaidi, A.A., and Hallan, V. 2013. Biological and molecular characterization of Cucumber mosaic virus subgroup II isolate causing severe mosaic in cucumber. Indian Journal of Virology., 24:27-34.

Lockhart, B.E.L. and Fischer, H.U. 1976. Cucumber Mosaic virus infections of pepper in Morocco. Plant Disease Reporter., 60: 262-264.

Perry, K.L., Habili, N. and Dietzgen, R.G. 1993. A varied population of Cucumber Mosaic virus from peppers. Plant Pathology., 42: 806-810.

Roossinck, M.J., Zhang, L. and Hellwald, K.H. 1999. Rearrangements in the 59 nontranslated region and phylogenetic analysis of Cucumber mosaic virus RNA 3 indicate radial evolution of three subgroups. Journal of Virology., 73: 6752-6758.

Sevik, M.A., Ondokuz M.U., Ziraat, F. and Bitki, K.B. 2003. Viruses Infecting Cucurbits in Samsun, Turkey. Plant Disease., 87:341-34.

Soleimani, P., Hosseini, S. and Hosseini, A. 2014. Distribution of some viral disease on pepper (Capsicum annum) plants in Dezful fields from Iran. Bulletin of Environment, Pharmacology and Life Sciences., 3: 111-114.

Verma, L.R. and Sharma, R.C. 1999. Diseases of Horticultural Crops, Vegetables, Ornamentals and Mushrooms. Indus Publishing., 724p.

Xu, B.L., Hong-Sheng, S. and Xu, W. 2006. Comparison of resistance to CMV particle and to CMV-RNA in transgenic chili pepper expressing CMV and TMV coat proteins. Acta Phytopathologica Sinica., 32: 132-137.

\section{How to cite this article:}

Shelly Kapoor, Abhilasha Sharma and Anil Handa. 2018. Correlation between Symptoms and ELISA for the Detection of Cucumber Mosaic Virus in Bell Pepper. Int.J.Curr.Microbiol.App.Sci. 7(06): 400-406. doi: https://doi.org/10.20546/ijcmas.2018.706.045 